\title{
Civic and Social Competences and the Patriotic Education of Small Children
}

In recent years, politicians, parents, educators, and psychologists have extensively discussed the topic of the education of children. Changes in education pertain to varying degrees to children's daily school experiences, and the issue of the education of children is particularly important to consider as cultures change. Providing school age children with the proper tools and skills allows them effectively and constructively participate in society and civic life. Patriotic education specifically teaches children how a united national consciousness can exist in a multicultural society. Patriotism also entails preserving and expressing one's culture and the beauty of one's native language.

Key words: social competence, civic competence, patriotism, early childhood education.

\section{Introduction}

Children organize their perception of reality from the point of view of values beginning with their contact with their surroundings and then throughout preschool and elementary school. During this period, children's knowledge about their surroundings increasingly broadens. The majority of what children experience and take in is processed and transformed in their minds.

Over time, different models and views on how to raise children to become wise and noble human beings have changed. This is evidenced in the fact that students, educators, psychologists, sociologists, and 
theologians have attempted to create educational models and theories (e.g., Homeric; Spartan; Athenian; optimistic and humanistic education of the Renaissance, Jan Jakub Rousseau's views, Johann Friedrich Herbert's views, Johan Dewey's ideas, and H. Rickert and Sergei Hessen's works) that explain how to raise children and that, if followed, would result in desired educational outcomes. From among the different theories and models, Sergei Hessen's speaks about so-called "objective" values, which is the foundation of what many pedagogists today call "values education" or "values-based education." In this way, values have become specific reference points when considering options for patriotic and civic education.

Early childhood education programs have and will continue to include teaching children basic human skills, such as: self-awareness, self-control, listening, conflict resolution, peer interaction, and patriotism. However, in our contemporary world where integration of cultures and peoples is taking place at a quick rate, there is a simultaneous fear of acts of violence against countries and peoples. With this reality in mind, parents and those involved in early childhood education are aware of their obligation to raise and teach children to know and love their nations' traditions, culture, and historical memory. In this way, the school class becomes like a mirror for children in which their weaknesses, successes, and sense of fulfillment are reflected. Within the school community, children get to know their civic rights and learn humility through serving others.

On December 18, 2006, the European Parliament and Council specifically defined the key competences of lifelong learning. These competences were determined in order to elevate teaching standards in the European Union (EU) and to create a uniform standard of education that is suitable for all member countries of the EU. According to the Council's definition, "Competences are defined here as a combination of knowledge, skills and attitudes appropriate to the context. Key competences are those which all individuals need for personal fulfillment and development, active citizenship, social inclusion, and employment."1 The concept of competence means many things. Etymologically, the term "competence" comes from the Latin "cum petere," which means to expect or anticipate; to go toward (something); to be fit (to do something); to occupy a certain position. ${ }^{2}$ The ambiguous

\footnotetext{
$1 \quad$ Kluczowe Kompetencje-europejski azymut dla edukacji, PDF, 2, http://www. refernet.pl/pl/publikacje/artykuly.html (Accessed: 10.27.2014).

$2 \quad$ M.Szymczak, "Kompetencja,"Stownikjęzyka polskiego,(Warsaw: Wydawnictwo PWN, 1978), 977.
} 
concept of competency is determined by other such concepts as: ability, efficiency, skill, talent, attributes, disposition, responsibility, conformity, authority, and the scope of someone's knowledge. ${ }^{3}$ There are many definitions of competence and, depending on the context, these definitions emphasize the following individual components of competence: abilities, personality traits, knowledge, and experience. For example, the definition that emphasizes action says that competence is "the ability and willingness to perform tasks at a certain level; the learned ability to do things well; the skills necessary to deal with problems." 4 Another definition of competence emphasizes interaction and communication: "the ability to behave and communicate according to the conditions, requirements, and expectations of a given situation." If, therefore, a person can perform a certain task, then this means that this person has the ability to do so. When this task can be completed under specific conditions (time, number of activities, speed, location, situation, etc.) and when an individual is aware of these conditions, then this person is competent in this specific area. ${ }^{6}$

In pedagogical literature, there are various definitions of the word "competence." According to Vincent Okoń, competence is "the ability to personally fulfill one's self" and the result of the learning process. ${ }^{7}$ Discovering children's natural competences is the first step in helping them to develop those competences that are weaker. Maria Czerepaniak Walczak states that competence is "a special attribute expressed in a person's ability to behave appropriately and accept responsibility for his behavior." In other words, competence is the thoughtful and precise implementation of knowledge that a person either has or has gained through practice. During this process, people improve in making the right decisions and acting appropriately. Competences are not the same as requirement standards, which are usually divided into categories such as reading, writing, reasoning, and the practical implementation of knowledge. These categories determine skills, or

$3 \quad$ M. Chrost, Kompetencje emocjonalne i społeczne młodziėzy (Cracow: Wydawnictwo WAM, 2011), 22.

4 Stownikwspótczesnyjęzyka polskiego, Vol.1(Warsaw: Przeglad Reader's Digest, 1998), 447.

5 I. Kurcz, Język a psychologia (Warsaw: Wydawnictwa Szkolne i Pedagogiczne, 1992), 89.

6 Ibid.

$7 \quad$ W. Okoń, Nowy słownik pedagogiczny (Warsaw: Żak, 1996), 129.

$8 \quad$ M. Czerepaniak-Walczak, Aspekty i źródła profesjonalnej refleksji nauczyciela (Torun: Edytor, 1997), 87-88. 
the practical knowledge of something, proficiency in something, and the ability to execute a certain action. Competence is the scope of an individual's knowledge and skills. Therefore, competence is a concept that is superior to skills, or it can be called a skill of a higher order.

A competent student is one who has mastered a number of basic skills and has knowledge of where, when, and how to use them. Hence, competence refers to a person, while skills refer to concrete actions. Children who begin school might already have a set of qualities that set them apart as being competent in a specific area. This involves many factors, including their psychophysical development and, most importantly, the families and environments in which the children are raised. Young people who finish higher education know from a young age that they cannot professionally stop where they were and that they need to keep developing themselves and their competences in order to have a firm foundation of knowledge from which to move professionally forward and higher. Consequently, knowledge and skills are not enough to succeed; rather, individuals need to know how to efficaciously use the skills that they have acquired. ${ }^{9}$

\section{Social and Civic Competences and the Education of Small Children}

Social and civic competences are personal, interpersonal, and intercultural. These competences include a range of behaviors that prepare people to effectively and constructively participate in social and professional life, especially in societies where diversity is increasing and conflict resolution is necessary. Civic competences prepare people to fully participate in civic life based on their knowledge of social and political concepts and structures and their sense of active and democratic participation. Such participation is manifested as knowledge about proper behavior and respect for the norms and principles of social and communal life.

Environments and cultures that foster co-existence and collaboration are essential for children to develop healthily and harmoniously; for, it is within such environments that children can best achieve a variety of competencies. A harmonious school environment also fills children with a sense of well-being and sets clear and socially acceptable boundaries for their behavior. In most cases, students who are

$9 \quad$ A. Kienig, "Kompetencje społeczne i obywatelskie," Rozwijanie kompetencji kluczowych uczniów w procesie edukacji wczesnoszkolnej, eds. J. UszyńskiejJarmoc, B. Dudel, and M. Głoskowskiej-Sołdatow (Cracow-Bialystok: Oficyna Wydawnicza "Impuls," 2013). 
cheerful and confident in their educational progress are most successful at school. In addition, these students are highly motivated to engage in cognitive activity. ${ }^{10}$

Social competence also includes the ability to communicate well. The majority of conflicts between people throughout the world, regardless of their cultural, national, material, or any other status, arise from misunderstandings. For both children and adults, the ability to properly communicate is key life skill based on: establishing and maintaining relationships with peers and adults, assertiveness, responsibility for what one says, controlling negative emotions, conviction, and self-acceptance. The ability to adapt to situations is closely related to an ability to communicate well. For small children, competence in adapting to situations is difficult to achieve and greatly depends on their parents' style of parenting. ${ }^{11}$ Social competences are linked to the good of a person and of society, which requires that a person be aware of how to achieve optimal physical and mental health. Societal and personal good can also be understood as an individual's resources, his family, and his environment and how a proper lifestyle can contribute to these goods.

Civic competences are based on knowledge of democratic concepts, justice, equality, citizenship, and civil rights as they are formulated in the EU's Charter of Fundamental Rights, in international declarations, and in adaptations by various local, regional, national, European, and international institutions. These competences also include knowledge about contemporary local, European, and world events, trends, and history. In addition, they exist into order to increase awareness about the goals, values, and policies that guide social and political movements. Knowledge about European integration and the EU's organizations (and their main aims and values), as well as awareness of the diversity and cultural identities in Europe are essential. ${ }^{12}$

Civic competence is also based on cooperation, assertiveness, and integrity. Civically competent individuals should be interested in socioeconomic development and intercultural communication. They should also value diversity and respect other people. In addition, individuals should be prepared to overcome prejudices and willing to compromise. Complete respect for human rights, including for equality as the basis for democracy and for different religions and ethnic

$10 \quad$ Ibid.

11 H. R. Schaffer, Key Concepts in Developmental Psychology (London: Sage Publications, 2006).

$12 \quad$ A. Kienig, "Kompetencje społeczne i obywatelskie." 
groups, is the foundation of a positive attitude. A positive attitude also entails both the sense of belonging to ones own environment, country, the EU, Europe at large, and to the world, along with a willingness to participate in democratic decision-making at all levels. Individuals who are civically competent have a sense of duty to their homeland as well as respect for the common values and democratic principles that ensure that their community is united. Constructive participation also includes civic activity; promoting diversity, social cohesion, and sustainability; and respect for the values and privacy of others.

\section{Civic Education as the Context of Virtues Education}

According to Wincenty Okoń, civic education "includes all of a student's educational influences and activities in order to teach him how a modern state functions, what the obligations and rights of the citizens of a given state are, and how citizens fulfill their duties and exercise their rights." 13 The EU is very involved in promoting civic education. Through numerous reports, including "Education: A Hidden Treasure" and "Educating Citizens in European Schools," the EU has tried to make Member States aware of the importance of this matter. ${ }^{14}$ The EU is committed to teaching others how to connect with local, regional, national, and European communities. It emphasizes the importance of these communities by asserting that they help people to develop and function in the world. ${ }^{15}$

There are many opportunities to strengthen patriotic values at school, including preparing students for and actively participating in national holidays and celebrations that commemorate the school patron. For example, within schools it is possible to emphasize the importance of the school uniform and banner as well as the national flag and hymn on every special occasion. In addition, students have daily opportunities to learn how to be responsible for their classroom, playground, school, and neighborhood, which will instill in them the skills necessary to be responsible for their societies and country as adults. ${ }^{16}$

\footnotetext{
13 W. Okoń, Nowy stownik, 349.

14 D. Lange and M. Print, Civic Education and Competences for Engaging Citizens in Democracies, E-Book (Rotterdam: Sense Publishers, 2013), 3-4.

15 J.Uszyńska-Jarmoc, “Teoretyczne źródła modelu edukacji obywatelskiej,” in E. J.Kryńska, Patriotyzm, a wychowanie (Bialystok: Wydawnictwo Uniwersyteckie Trans Humana, 2009), 345-346.

16 H. Radziewicz, "Wychowanie patriotyczne w edukacji wczesnoszkolnej," Wychowawca, no. 9 (2007): 16.
} 
Excursions are some of the best opportunities for students to get to know their culture and history. Direct contact with nature and their cultural heritage influence students' intellectual, social, and emotional development. By going outside of their schools, students encounter other people and the work that they do. Through these encounters, students learn proper social attitudes. In addition, new experiences enrich students' vocabulary, improve their imaginations, and make them more sensitive to the beauty that surrounds them. ${ }^{17}$

In our present time, civic education should strive to teach how to solve social problems and influence institutions according to democratic principles. To this end, children should be prepared to one day serve and support their local communities, country, and the EU as adults. Children should also be taught to respect the opinions of others (when creating a legal system) and have an unbiased approach to others. ${ }^{18}$

Civic education is strongly connected with history and the fundamental processes of modern social life. Such education can be approached in at least three ways. First, civic education is the subject of the history of education. In this case, civic education refers a given community's level of maturity; which includes the organization and continual improvement of the state's defense, economy, and sociocultural life. Secondly, democratic education is the subject of axiology, which depends on social and moral values. Specifically, democratic education concerns citizens' understanding of how a nation develops and overcomes contradictions between the values of the state, the nation, and the spiritual and human life of the citizens. Thirdly, patriotic education is the subject of education theory. As such, it refers to psychological attitudes. Such an approach to the problem of civic education makes it possible to examine the philosophical and historical science of patriotism as well as citizens' attitudes and experiences with regard to the needs of their country. ${ }^{19}$ Citizenship, nationality, patriotism, and culture are connected with civic education. Each of these concepts has many meanings and is interpreted differently depending on the historical time period and the views of a given society.

17 D. Wojtek, "Edukacja poza szkolną ławką-poznajemy swoją mała i wielką ojczyznę,” Życie Szkoły, no. 5 (2004), 14-16.

18 M. Cern, P. Juchowicz, and E. Nowak, Edukacja demokratyczna (Poznan: Wydawnictwo Naukowe Instytutu Filozofii Uniwersytetu im. Adama Mickiewicza, 2009), 8-9.

19 L. Zarzecki, Teoretyczne podstawy wychowania. Teoria i praktyka $w$ zarysie (Jelenia Gora: Karkonoska Państwowa Szkoła Wyższa, 2012), 120-122. 
According to Stanislaw Kowalczyk, homeland is the "country, or land, of [one's] ancestors; a community of people linked by the bonds of blood; and above all the community of [a common] language, culture, customs, and history." ${ }^{20}$ Homeland should also be understood as an organized space containing family homes and neighborhoods; a region; a country; and Europe. For this reason, literature distinguishes between two concepts of homeland: large and small. A large homeland is the country in which a person was born, lives, and associates through its traditions and the person's spiritual attachment. A small homeland, on the other hand, is a component of the large homeland; it is the place and region where people are born or live. Attachment to a small homeland is best evidenced in the concern a person shows for its common good. For each person, however, attachment to one's homeland may mean something completely different, since attachment is associated with a person's memories of the carefree years of childhood. $^{21}$

\section{The Patriotic Education of Small Children}

Patriotism is a person's love for his homeland. Today, however, the concept of patriotism is not always confined to one's nationality. For, those who live in the majority of countries throughout the world are not necessarily from them. This multiculturalism enriches the global culture and makes its expression unique. Individual national consciousness allows a person to find his own place in a multicultural society. On a broader level, the democratic process and other factors that unite a society also revive it. ${ }^{22}$ Patriotism is also preserving, caring, and fostering one's culture and the beauty of one's native language; passing on and learning the history of one's country and its customs; and responding to human problems that arise in society (breaking the law and public misconduct). ${ }^{23}$

$20 \quad$ S. Kowalczyk, "Pojęcie ojczyzny," in K. Chałas and S. Kowalczyk, Wychowanie ku wartościom narodowo-patriotycznym (Lublin-Kielce: Jedność, 2006), 34. wska, Dziecko wświecie wielkiej i matej ojczyzny (Cracow: Oficyna Wydawnicza "Impuls," 2009), 17-55.

22 J. Gajda, “Żywe tradycje, a wspótczesność w podejmowaniu patriotyzmu,” in E. J. Kryńska, Patriotyzm, a wychowanie (Bialystok: Wydawnictwo Uniwersyteckie Trans Humana, 2009), 48-49.

$23 \quad$ J.Salij, "Patriotyzm dzisiaj,” W Drodze (Poznan: Wydawnictwo W Drodze, 2005), 19-20. 
According to L. Zarzecki, the nation is "a general population of people formed on the basis of culture, language, a common national consciousness, a strong sense of belonging, and solidarity." ${ }^{24}$ Free citizens with dignity and wisdom are the basis of every democratic nation. Their most important task is to build a just society and serve the common good. The development of a national community, which would be impossible without the continuous enrichment of its culture, is the condition for its existence. ${ }^{25}$

Culture is made up of a people's spiritual and material achievements that have been fostered and enriched by all generations over many centuries. Culture includes art, science, religious values, and national traditions. In the broad sense of the term, culture also includes individual views of the world. Usually, culture constitutes an integral part of the homeland and nation. ${ }^{26}$

The formation of civic attitudes is closely related to the socialization of the individual. At the elementary school level, educators focus on teaching students languages, historical traditions, and customs in order to shape their sense of community and make them aware that they live in a specific society. The successive stages of educational influence are comprised of two elements: intellectual-communicating the attributes of social, political, legal, and economic knowledge and the skills based on this knowledge, and moral-shaping civic and pro-social attitudes. ${ }^{27}$ The intellectual element forms the foundation for moral development. Within the context of education, citizenship can be understood in many different ways. For this reason, various models of civic education foster the formation of different types of citizens. The goal of civic education is to make children feel like citizens, foster their bond with their homeland, and think about where they live. This, in turn, makes it easier for students to engage in civic life and discourse. It is so important for students to receive a civic education from an early age so that their knowledge about a given area and region can increase. When individuals find resources in their own

$24 \quad$ L. Zarzecki, Teoretyczne podstawy wychowania, 126.

25 K. Hałas, "Teoretyczne podstawy wychowania ku wartościom narodowopatriotycznym," in K. Hałas and S. Kowalczyk, Wychowanie ku wartościom narodowo-patriotycznym (Lublin-Kielce: Jedność, 2006), 138-143.

$26 \quad$ M. Łobocki, Teoria wychowania w zarysie (Cracow: Oficyna Wydawnicza "Impuls," 2006), 290.

27 S.M. Lipset, Homo politicus. Spoteczny wymiar polityki (Warszawa: Wydawnictwo PWN, 1998). 
communities, then they can build relationships with their local and regional communities.

\section{The Local Environment}

According to Tadeusz Pilch, the pedagogical definition of a local society is: "a group of people living in a restricted and relatively isolated territory, who have distinct yet common values, traditions, symbols, service and cultural institutions, a united consciousness, a willingness to collaborate, a sense of belonging, and internal security." 28

A local environment is an immediate human environment that is comprised of, on the one hand, the natural environment (now strongly influenced and changed by human interactions) which conditions social behavior, and, on the other hand, the social environment which is made up namely of family, peers, and neighborhoods and participates in national or state associations, organizations, structures, or religious community. $^{29}$

The traditional concept of a local social environment and its influence on individuals indicates that the social environment "encompasses a group of people and cultural works that are permanently 'close,' yet individually affected by the environment." 30 The scope of the environment is determined by the closeness of the surroundings or the spatial mobility of those who live within the environment. In addition to the social community that inhabits a small or relatively enclosed area, the local environment also means the whole system of institutions that organize and affect the inhabitants' lives, such as schools, service institutions, social or recreational facilities, as well as the mechanisms that regulate individual behavior and interpersonal relations, such as morality, social norms, and patterns of behavior.

Ryszard Wroczyński defines the local environment as a "set of objective developmental and educational identifiers, in particular: objectively existing and relatively permanent elements of the environment's structure, which give rise to specific developmental stimuli." ${ }_{31}$ The

T. Pilch and I. Lepalczyk, eds., "Środowisko lokalne-struktura, funkcje przemiany," Pedagogika społeczna (Warsaw: Wydawnictwo Ekonomiczne “Żak," 1995), 158.

Z. Ziembiński, Elementy socjologii (Poznan: Wydawnictwo Ars Boni et Aequi, 1993), 22.

T. Pilch and I. Lepalczyk, eds., "Środowisko lokalne," 155.

31

R. Wroczyński, Pedagogika społeczna, $4^{\text {th }}$ Edition(Warsaw: Wydawnictwo PWN, 1985). 
author points out the following as elements of the local environment: the geophysical system, traditions, demographics (population distribution), professional diversity, sociocultural activity, economic structure, and industrialization.

The environment is a very complex and changing concept that can be considered in terms of time (e.g., historical, contemporary, social) or space (e.g., institutions, place of residence). These are all external factors that affect human life and development and form students' principles, views, attitudes, and moods, which can change according to each person's needs. ${ }^{32}$ According to Vincent Okon, the environment is "all of the ecological, economic, political, social, cultural-educational, and institutional processes in their relationships with and dependence on each other. It is a space where society engages in various activities, creates living conditions, and satisfies spiritual and material needs." 33 The author distinguishes four types of environment: didactic, cultural, local, and social. Each type has an impact on children's socialization, but the local environment is particularly responsible for shaping children's civic attitudes.

Besides the family, the local community is one of the most important groups actively involved in raising and forming children. The group of people who live in a given area, their traditions, their symbols, and their local cultural and service institutions determine the local community. ${ }^{34}$ The local community is also a range of generally defined features, mechanisms, and elements that, likewise, determine the educational environment. The local community is characterized by the fact that residents are aware of belonging to it, and they help each other in case of threats or danger. In local communities, special volunteer organizations, social associations, and neighborhood communities are established to provide, for example, family support programs and childcare. Within these communities, children often stay in close contact with their peers, and this fosters parental integration. Human relationships serve to enrich the community members' lives and strengthen their sense of security.

The local environment changes rapidly. Nowadays, closed communities that are confined to their traditions and attached only to family property and assets are disappearing, and open communities are taking their place. Within an open community, people work outside of

32 J. Karbowniczek, Maty leksykon pedagoga wczesnoszkolnego (Warsaw: Instytut Wydawniczy Erica, 2014), 251.

$33 \quad$ W. Okoń, Nowy stownik, 392.

34 T. Pilch and I. Lepalczyk, eds., "Środowisko lokalne," 75-76. 
their homes and neighborhoods, belong to a variety of organizations, and have friends and acquaintances in other nearby towns, cities, and even countries. ${ }^{35}$

\section{Patriotic Education - Thematic Trends in the Formation of Small Children}

Patriotic education is an extraordinarily strong phenomenon and directly related to many basic processes of social life. However, its essential character has historical implications. The process of forming individuals' national consciousness and identification with their homeland has evolved over a very long time. As cultures have developed, so too has the essence of patriotic feelings been continually enriched and transformed. Through knowledge and contact with their nation's past, communities become not only heirs but also the creators of new cultural, moral, and social values. ${ }^{36}$

Patriotic education is generally understood as instilling in or teaching children to love their own country and nation and be willing to sacrifice themselves for it. Rather, the purpose of patriotic education is to prepare pupils to best serve their own nation and country. Above all else, patriotic education should foster in children affection and love for their homeland (past and present) and to strengthen their sense of responsibility for its comprehensive development and place among other countries. ${ }^{37}$ Patriotic education is also defined as consciously and deliberately influencing children and young people in order to foster in them patriotic attitudes, meaning an attachment to and love for their homeland, solidarity with its inhabitants, and a willingness to sacrifice themselves for the common good. ${ }^{38}$ In addition, the purpose of patriotic education is to instill in individuals a readiness to defend their own homeland and contribute to its security.

Patriotic education strongly emphasizes the assimilation of children and young people into society by educating them about their homeland, passing on their nation's national and regional history, and sharing the nation's national and regional culture and geography. In order

$35 \quad$ S. Kawula, Pedagogika społeczna dokonania-aktualności-perspektywy (Torun: Wydawnictwo Adam Marszałek, 2009), 140-141. 
to love one's nation, its history, and its culture, and to be charmed by the beauty of its nature, all of these things must be known..$^{39}$

In order to properly understand patriotic education, it is necessary to be familiar with conceptions such as nation, homeland, culture, and patriotism. Each of the following concepts is closely linked to the aims of patriotic education:

NATION - commonly understood as a group of people formed according to and sharing in a common culture, language, and national consciousness. This group is distinguished by a strong sense of belonging to the nation as well as solidarity among its members.

HOMELAND - the country in which a person was born or spent a significant part of his life and to which he feels emotionally connected. The word "homeland" is also associated with a specific territory and, even more, with established laws than with national customs and traditions.

CULTURE - the entirety of a given nation's material and spiritual achievements that have been gathered, preserved, and enriched throughout its history and passed down from one generation to another.

PATRIOTISM - a concept closely related to patriotic education. $\mathrm{Pa}$ triotism contains in itself love for one's homeland and the nation. This love involves working for one's homeland and sacrificing oneself for the common good. Patriotism is manifested not only in an emotional attachment to one's nation and homeland, but also in the fulfillment of one's civic duties and obligations. ${ }^{40}$ Today, patriotism involves caring for the beauty, purity, and richness of one's language and rooting oneself and the next generation in one's native culture, meaning nourishing oneself from what is noblest in it. ${ }^{41}$

A patriotic attitude includes the following: love for one's homeland, serving one's country, interest in one's nation's affairs, loyalty to the leaders of one's nation, readiness to defend the interests and security of one's nation, and respect for national symbols (emblem, anthem, flag, ceremonies on national and state holidays, etc). ${ }^{42}$

As a positive attitude toward one's homeland and its problems, patriotism should be a virtue at the foundation of the work of educators who should show children and youth the glorious as well as the tragic

$39 \quad$ J. M. Bocheński, O patriotyzmie (Warsaw: Wydawnictwo Odpowiedzialność i Czyn, 1989), 18.

$40 \quad$ M. Łobocki, Teoria wychowania, 288-289.

$41 \quad$ J. Salij, "Patriotyzm dzisiaj," 19.

42 L. Zarzecki, Teoretyczne podstawy wychowania, 126. 
events of their nation's history. Patriotism not only appreciates the independence and sovereignty of one's homeland and the magnitude of its historical events, but also the formation of citizens' attitudes, observance and respect for the law, and conscientious fulfillment of one's duties. Parental neglect in fostering patriotism is evident only in situations where, for example, students do not know how to behave during school or state celebrations. It is important to create educational circumstances that help evoke patriotic attitudes in students. ${ }^{43}$

Patriotism is often called local patriotism and, therefore, associated Miscellanea with a person's homeland-the place where he was born, where he grew up, and where his family roots have taken hold. ${ }^{44}$ For this reason, children should be taught their native language as well as the history of their families and their closest surroundings at a very early age so that they can come to love "what is theirs." 45

Patriotic education is a means to develop the personalities of members of younger generations, to form their attitudes toward their own societies, and to help them understand their particular society's place in the world. The aim of patriotic education is to foster in citizens a feeling of belonging to their own nation and instill respect for and attachment to the tradition's of their own nation, its achievements, culture, native language, and inhabitants. ${ }^{46}$ However, only when citizens effectively protect that which is closest to them and live with awareness of their own roots and identity, can a person naturally grow from a "small" to a "large" homeland.

\section{The EU's Educational Policy Concerning Contemporary Early Education}

In 1921, the International League for New Education complied the first list of competences that are necessary for life and acquired through education. The authors of the list were concerned about man's personal freedom, rights, and dignity. In January 1997, the Ministry

$43 \quad$ I. Stańczak, "Wychowanie patriotyczne a treści programowe i proces nauczania zintegrowanego,” Nauczanie początkowe: Ksztatcenie zintegrowane Edukacja patriotyczna, no. 1(2007/2008): 36.

44 W. Theiss, "Mała ojczyzna: perspektywa edukacyjno-utylitarna," in Mała ojczyzna. Kultura Edukacja Rozwój lokalny, ed. W. Theiss (Warsaw: Wydawnictwo Akademickie "Żak," 2001), 11-13.

45 K. Ziołowicz, "Edukacja regionalna jako element edukacji patriotycznej," Nauczanie poczatkowe: Kształcenie zintegrowane Edukacja patriotyczna, nr. 1 (2007/2008): 42-43. 
of Education published the first version of the fundamentals of general education curriculum in its Education Strategy. This publication presented not only the concept of skills, but also the concept of competences. According to this document, children in European schools develop the following social competences in the initial stage of their education: readiness to participate in different situations, an ability to respond to situations, communication, discussion, argumentation, listening to others, problem-solving, negotiating, and emotional resilience in difficult situations. Civic education for young children is current and takes into consideration the continual societal changes that are taking place in the modern world. The EU's Member States have a special responsibility to shape the civic attitudes of their members and respect the traditions and cultures of those both in and outside of the EU.

The EU is an economic and political union of European countries known as Member States. The Member States' cooperation in this organization also entails their cooperation in the EU's common educational policy. The EU became involved in educational policy later than it did in, for example, economic cooperation. In 1973, the EU published its first report on education policy entitled For a Community Policy in Education. In 1974, the Education Committee was established, and the EU Council of Ministers of Education approved the first educational policy program in 1976. The EU's most important educational issues are mentioned in it's founding Treaty of Maastricht, ${ }^{47}$ which was signed in 1992, enforced in 1993, and included the EU's first discussion on educational policy. The EU's education policy lists certain priorities that relate to, among others, the following issues:

- Equal educational opportunities for children: regardless of sex, country of origin, language, religion, mental and physical (dis)ability; to protect the lives and health of students

- Improve the quality of education through: program reform and greater flexibility in teaching structures; developing new ways of acquiring knowledge and skills; fighting school and social exclusion of students; education for peace and democracy; tolerance toward other people's differences in accordance with the Human Rights Convention.

The EU's educational policy is common to each of its Member States. A variety of factors determine all aspects of the organization of the EU's education systems. Among the most important factors are: traditions,

M. Mazińska, Polityka edukacyjna Unii Europejskiej (Warsaw: Wydawnictwa Szkolne I Pedagogiczne, 2004), 26. 
social processes, and the influence of the economy. While the age of compulsory education varies in the EU, it averages between ages 4 to 7 years. In the vast majority of countries, children begin school at 6 years of age. In the United Kingdom and the Netherlands, children begin school at 5 years of age. In Denmark, Sweden, and Finland, children begin attending school at 7 years of age.

In early education in most countries, one teacher teaches all of the subjects. Denmark, however, follows a different model where different teachers teach each subject. Obviously, each country teaches its own native language. And, there are evident differences in the teachings of different religions and ethics. While foreign languages are taught in almost every country, it is obligatory for students to learn modern languages. ${ }^{48}$ In most European countries, students repeat a class only in exceptional circumstances during the early years of their education.

In Denmark, Iceland, Sweden, and Norway, students are also automatically promoted to the next class. When a child has difficulty learning or coping well in social situations, specialists are available to help. These countries also provide "outdoor education," meaning education that takes place outside of the school in the open air. This form of education has many pedagogical aims, including the experience of nature, respect for one's cultural heritage, recognizing the beauty of the surrounding world, and concern for nation's the common good and heritage. Thus, in many ways, cultural competence complements social and civic competence in the education of young children. When analyzing the key competences, one should also keep in mind that practical implications stem from the basic assumptions of pedagogy based on cognitive and social constructivism.

\section{KOMPETENCJE OBYWATELSKIE, SPOLECZNE I WYCHOWANIE PATRIOTYCZNE MAŁEGO DZIECKA}

W ostatnich latach edukacja dzieci stała się przedmiotem intensywnej dyskusji polityków, rodziców, pedagogów i psychologów. Te obszary zmian edukacyjnych w różnym stopniu dotyczą codzienności szkolnej dziecka. W sytuacjach przełomu kulturowego zawsze zwracamy się w stronę wychowania dziecka. Kształtowanie kompetencji społecznych i obywatelskich przygotowują ucznia w młodszym wieku szkolnym do skutecznego i konstruktywnego uczestnictwa w życiu społecznym. Natomiast wychowanie patriotyczne uczy jak jednostkowa

48 A. Seredyńska, Zarys pedagogiki porównawczej (Cracow: Wydawnictwo WAM, 2006), 73 . 
świadomość narodowa pozwala odnaleźć się w wielokulturowym społeczeństwie. Patriotyzm to jednocześnie dbanie o kulturę i piękno ojczystego języka.

Słowa kluczowe: kompetencje społeczne i obywatelskie, patriotyzm, edukacja wczesnoszkolna.

\section{Bibliography:}

1. Bilicki, T. Dziecko i wychowanie w pedagogice Jana Pawta II. Idee-metodyinspiracje. Cracow: Oficyna Wydawnicza "Impuls," 2000.

2. Bocheński, J. M. O patriotyzmie. Warsaw: Wydawnictwo Odpowiedzialność i Czyn, 1989.

3. Cern, M., P. Juchowicz, and E. Nowak. Edukacja demokratyczna. Poznan: Wydawnictwo Naukowe Instytutu Filozofii Uniwersytetu im. Adama Mickiewicza, 2009.

4. Chrost, M. Kompetencje emocjonalne i społeczne mtodzieży. Cracow: Wydawnictwo WAM, 2011.

5. Czerepaniak-Walczak, M. Aspekty i źródła profesjonalnej refleksji nauczyciela. Torun: Edytor, 1997.

6. Denek, K. "Poszukiwanie drogi." In K. Denek, B. Dymara, and W. Korzeniowska, Dziecko w świecie wielkiej i małej ojczyzny. Cracow: Oficyna Wydawnicza "Impuls," 2009.

7. Gajda, J. "Żywe tradycje, a wspótczesność $w$ podejmowaniu patriotyzmu." In E. J. Kryńska, Patriotyzm, a wychowanie. Bialystok: Wydawnictwo Uniwersyteckie Trans Humana, 2009.

8. Hałas, K. "Teoretyczne podstawy wychowania ku wartościom narodowopatriotycznym." In K. Hałas and S. Kowalczyk, Wychowanie ku wartościom narodowo-patriotycznym. Lublin-Kielce: Jedność, 2006.

9. Janicka, I., and H. Liberska, Eds. Psychologia rodziny. Warsaw: Wydawnictwo Naukowe PWN, 2014.

10. Jęczeń, J., and M. Z. Stepulak, Eds. Wartość $i$ dobro rodziny. Lublin: Wydawnictwo KUL, 2011.

11. Kawula, S. Pedagogika społeczna dokonania-aktualności- perspektywy. Torun: Wydawnictwo Adam Marszałek, 2009.

12. Kienig, A. "Kompetencje społeczne i obywatelskie," Rozwijanie kompetencji kluczowych uczniów w procesie edukacji wczesnoszkolnej. Edited by J. Uszyńskiej-Jarmoc, B. Dudel, and M. Głoskowskiej-Sołdatow. CracowBialystok: Oficyna Wydawnicza "Impuls," 2013.

13. Kluczowe Kompetencje-europejski azymut dla edukacji, PDF, 2, http://www. refernet.pl/pl/publikacje/artykuly.html (Accessed: 10.27.2014).

14. Kowalczyk, S. "Pojęcie ojczyzny." In K. Chałas and S. Kowalczyk, Wychowanie ku wartościom narodowo-patriotycznym. Lublin-Kielce: Jedność, 2006.

15. Kurcz, I. Język a psychologia. Warsaw: Wydawnictwa Szkolne i Pedagogiczne, 1992.

16. Lange, D., and M. Print, Civic Education and Competences for Engaging Citizens in Democracies, E-Book. Rotterdam: Sense Publishers, 2013. 
17. Lipset, S. M. Homo politicus. Spoteczny wymiar polityki. Warszawa: Wydawnictwo PWN, 1998.

18. Łobocki, L. Teoria wychowania w zarysie. Cracow: Oficyna Wydawnicza "Impuls," 2006.

19. Mazińska, M. Polityka edukacyjna Unii Europejskiej. Warsaw: Wydawnictwa Szkolne I Pedagogiczne, 2004.

20. Okoń, W. Nowy słownik pedagogiczny. Warsaw: Żak, 1996.

21. Pilch, T., and I. Lepalczyk, Eds. "Środowisko lokalne-struktura, funkcje przemiany." In Pedagogika społeczna. Warsaw: Wydawnictwo Ekonomiczne "Żak," 1995.

Miscellanea

22. Radziewicz, H. "Wychowanie patriotyczne w edukacji wczesnoszkolnej," Wychowawca, no. 9 (2007): 16.

23. Salij, J. "Patriotyzm dzisiaj," W Drodze. Poznan: Wydawnictwo W Drodze, 2005.

24. Schaffer, H. R. Key Concepts in Developmental Psychology. London: Sage Publications, 2006.

25. Słownik współczesny języka polskiego, Vol. 1. Warsaw: Przeglad Reader's Digest, 1998.

26. Seredyńska, A. Zarys pedagogiki porównawczej. Cracow: Wydawnictwo WAIM, 2006.

27. Stańczak, I. "Wychowanie patriotyczne a treści programowe i proces nauczania zintegrowanego," Nauczanie poczatkowe: Ksztatcenie zintegrowane Edukacja patriotyczna, no. 1(2007/2008): 36.

28. Strzałkowska, M. O wartościach, czyli rady nie od parady, Vol 3. Warsaw: Wydawnictwo Czarna Owca, 2012.

29. Strzałkowska, M. Rady nie od parady czyli wierszyki z morałem. Warsaw: Wydawnictwo Czarna Owca, 2007.

30. Strzałkowska, M. Raj na ziemi czyli rady nie od parady, Vol. 2. Warsaw: Wydawnictwo Czarna Owca, 2007.

31. Szymczak, M. "Kompetencja," Stownik języka polskiego. Warsaw: Wydawnictwo PWN, 1978.

32. Tchorzewski, A. M., Ed. Wychowanie w kontekście teoretycznym. Bydgoszcz: Wydawnictwo WSP, 1997.

33. Theiss, W. “Mała ojczyzna: perspektywa edukacyjno-utylitarna." In Mała ojczyzna. Kultura Edukacja Rozwój lokalny. Edited by W. Theiss. Warsaw: Wydawnictwo Akademickie "Żak," 2001.

34. Uszyńska-Jarmoc, J. “Teoretyczne źródła modelu edukacji obywatelskiej." In E. J. Kryńska, Patriotyzm, a wychowanie. Bialystok: Wydawnictwo Uniwersyteckie Trans Humana, 2009.

35. Uszyńska-Jarmoc, J., and M. Bilewicz, Eds. Kompetencje kluczowe dzieci i młodziė̇y. Teoria i badania. Warsaw: Wydawnictwo Akademickie “Żak," 2015.

36. Uszyńska-Jarmoc, J., and K. Nadachewicz, Eds. Kompetencje kluczowe dzieci i mtodzieży. Praktyka edukacyjna. Warsaw: Wydawnictwo Akademickie "Żak," 2015.

37. Wojtek, D. "Edukacja poza szkolną ławką-poznajemy swoją mała i wielką ojczyznę," Życie Szkoły, no. 5 (2004), 14-16. 
38. Zarzecki, L. Teoretyczne podstawy wychowania. Teoria i praktyka $w$ zarysie. Jelenia Gora: Karkonoska Państwowa Szkoła Wyższa, 2012, 120-122.

39. Ziołowicz, K. "Edukacja regionalna jako element edukacji patriotycznej," Nauczanie poczatkowe: Ksztatcenie zintegrowane Edukacja patriotyczna, nr. 1 (2007/2008): 42-43. 